\title{
Influence of casein phosphopeptides and lactulose on intestinal calcium absorption in adult female rats
}

\author{
R Brommage, MA Juillerat, $R$ Jost \\ Nestlé Research Centre, Nestec SA, Vers-chez-les-Blanc, \\ PO B44 CH-1000 Lausanne 26, Switzerland
}

\begin{abstract}
Summary - Fractional intestinal $\mathrm{Ca}$ absorption was measured in female rats by mixing ${ }^{47} \mathrm{Ca}$ and the nonabsorbable marker ${ }^{47} \mathrm{Sc}$ into purified diets and measuring the decrease in the ratio of ${ }^{47} \mathrm{Ca}$ to Scrierstas feces the diet. Ca absorption in 28 -wk-old rats consuming a $0.5 \%$ Ca diet was not significantly influenced by replacing whey protein with casein, casein phosphopeptides or phosphoserine. Ca absorption was doubled by adding $4 \%$ lactulose in both the presence and absence of casein phosphopeptides. Ca absorption in 56-wk-old rats consuming a $0.2 \%$ Ca diet was elevated a modest $26 \%$ by increasing the level of dietary casein from 9 to $27 \%$.
\end{abstract}

absorption / calcium / casein / lactulose / phosphopeptide

Résumé - Effets des phosphopeptides de caséine et du lactulose sur l'absorption intestinale du calcium chez le rat adulte. Une étude sur l'absorption intestinale du calcium chez le rat femelle a été effectuée à l'aide d'une technique de double marquage isotopique au ${ }^{47} \mathrm{Ca}$ et ${ }^{47} \mathrm{Sc}$. La fraction de $\mathrm{Ca}$ absorbée d'une diète donnée, a pu être calculée à partir des rapports ${ }^{47} \mathrm{Ca}$ sur ${ }^{47} \mathrm{Sc}$ dans ces régimes alimentaires et les selles, le ${ }^{47} S c$ n'étant pas absorbé. Aucun effet significatif sur l'absorption du Ca n'a pu être mis en évidence sur des rats âgés de 28 semaines lorsqu'une partie de la protéine sérique composant la diète est remplacée par de la caséine, des phosphopeptides de caséine ou par de la phosphosérine. En revanche, une adjonction de lactulose à $4 \%$ a provoqué une augmentation de $100 \%$ de l'absorption du $\mathrm{Ca}$, que les diètes contiennent ou non des phosphopeptides. Chez des rats âgés de 56 semaines, l'absorption du Ca n'augmente que de façon marginale (26\%), lorsque la quantité de caséine dans la diète est triplée (9-27\%).

calcium / caséine / absorption / lactulose / phosphopeptide

\section{INTRODUCTION}

Milk and dairy products are the most important dietary source of $\mathrm{Ca}$ in human life and the absorption of $\mathrm{Ca}$ from these products is high compared with other foods. The high lactose content of milk is usually considered to be a major factor responsible for the high $\mathrm{Ca}$ absorption from milk and dairy products. As reviewed by Miller (1989), lactose has repeatedly been shown to stimulate intestinal $\mathrm{Ca}$ absorption in rats. This beneficial effect of lactose was also observed in infants receiving a soy protein-based formula with either lactose or corn syrup as the carbohydrate source (Ziegler and Fomon, 1983). A cow's milk-based infant formula was shown to give higher bone mineralization in infants in comparison with a soybased, lactose-free formula (Steichen and Tsang, 1987). In adult humans the effect

\footnotetext{
* Correspondence and reprints
} 
of lactose on $\mathrm{Ca}$ absorption is still a matter of controversy (Miller, 1989).

In addition to lactose, casein has been suggested to further enhance $\mathrm{Ca}$ absorbability. The phosphorylated regions of the various bovine caseins are involved in stabilizing the colloidal $\mathrm{Ca}$ phosphate complex of cow's milk (Holt and Sawyer, 1988). Casein derived phosphopeptides bind metal ions (Oesterberg, 1966) and stabilize supersaturated $\mathrm{Ca}$ phosphate systems (Reeves and Latour, 1958; Gerber and Jost, 1986; Berrocal et al, 1989).

In vivo digestion of casein produces phosphopeptides which enhance the intestinal solubility of $\mathrm{Ca}$ according to Naito et al (1972). The amounts of soluble $\mathrm{Ca}$ and $P$ in rat intestine were higher after a meal with casein than other dietary proteins (Lee et al, 1980). The in vivo formation of a defined phosphopeptide was recently demonstrated in cannulated minipigs fed casein, and the casein fragment $\alpha_{\mathrm{s} 1}$ [6674 ] isolated by preparative HPLC (Meisel and Frister, 1988). These observations are compatible with a role of casein phosphopeptides on the intestinal solubility and absorption of $\mathrm{Ca}$ but they provide no direct evidence for a stimulation of $\mathrm{Ca}$ absorption.

A balance study with young pigs fed a $0.8 \% \mathrm{Ca}$ diet for $52 \mathrm{~d}$ showed no influence of $5 \%$ casein phosphopeptides on intestinal $\mathrm{Ca}$ absorption (Pointillart and Guégen, 1989). Despite the absence of a long-term effect, a transient stimulation of $\mathrm{Ca}$ absorption might have occurred. Thus, a short-term assay might be a more sensitive test of the ability of casein phosphopeptides to enhance $\mathrm{Ca}$ absorption. This approach was chosen in our study in which intestinal $\mathrm{Ca}$ absorption from $\mathrm{CaCO}_{3}$ was compared in rats fed diets containing whey protein, casein, casein phosphopeptides or phosphoserine as nitrogen sources.

\section{MATERIALS AND METHODS}

\section{Materials}

Lactulose and phosphoserine were purchased from Fluka, Switzerland. The whey protein isolate (BiPRO) was purchased from Bio-Isolates, UK and vitamin-free casein was purchased from ICN Biomedicals, USA. Casein phosphopeptides were produced as already described (Juillerat et al, 1989) by tryptic hydrolysis of whole bovine casein, followed by separation of the $\mathrm{pH} 4.5$ soluble peptides on an anion exchange column. Protein values were calculated from 6.38 times their nitrogen contents. Further details on these proteins are given in table I. ${ }^{47} \mathrm{Ca}$ and $\left[{ }^{3} \mathrm{H}\right]$ poly-ethyleneglycol were purchased from Amersham, England.

\section{In vitro stability of phosphopeptides}

The small intestine of an adult rat was dissected into 3 segments corresponding approximately to duodenum, jejunum and ileum. Each segment, including its contents, was immediately extracted with $5 \mathrm{ml}$ of ice-cold $0.02 \mathrm{M} \mathrm{pH} 8.0$ Tris- $\mathrm{HCl}$ buffer. Following removal of insoluble material by centrifugation, phosphatase activity was measured and found highest in the ileum. Casein phosphopeptides $(10 \mathrm{mg} / \mathrm{ml}$ ) were incubated with the Tris-buffered ileal extract for up to 3 $\mathrm{h}$ at $25^{\circ} \mathrm{C}$. Samples were chromatographed on a Mono-Q anion exchange column (Juillerat et al, 1989) and, from the decrease in the respective peak areas, the rate of dephosphorylation of the phosphopeptides was calculated. In order to measure the liberation of inorganic $P$ from the peptides, an aliquot of the incubation mixture was treated with $2 \mathrm{~N} \mathrm{H}_{2} \mathrm{SO}_{4}$ and assayed for inorganic $\mathrm{P}$ according to the procedure of Van Veldhoven and Mannaerts (1987).

\section{In vivo stability of phosphopeptides}

$1.5 \mathrm{ml}$ of a $40 \mathrm{mg} / \mathrm{ml}$ casein phosphopeptide solution in $0.1 \mathrm{M} \mathrm{CaCl}_{2}$ was administered together with $2 \mu \mathrm{Ci}$ of $\left[{ }^{3} \mathrm{H}\right]$ polyethyleneglycol by stomach gavage to a $250-\mathrm{g}$ rat. One h later the 
Table I. Ca and P contents of dietary components. Protein contents were calculated from 6.38 times the nitrogen contents. ND indicates that no measurement was performed.

Composition des éléments constituant le régime alimentaire. Un facteur de conversions de 6,38 a été utilisé pour calculer la quantité de protéines à partir de la teneur en azote. ND = non déterminé.

Component

\begin{tabular}{|c|c|c|}
\hline $\begin{array}{r}\text { otein } \\
6 \text { weight }\end{array}$ & $\begin{array}{l}\text { Calcium } \\
(\mathrm{mg} / 100 \mathrm{~g})\end{array}$ & $\begin{array}{l}\text { Total P } \\
(\mathrm{mg} / 100 \mathrm{~g})\end{array}$ \\
\hline
\end{tabular}

Casein

Whey protein

Casein phosphopeptides

Phosphoserine

Cornstarch

Cellulose

90.0
93.4
76.6
48.3
0.1
0

90.0

93.4

76.6

0.1

0
45.4

161.9

50.0

0

13.7

74.5

0.8
34.8
0.1
0.1
ND
0

1.1

1.5

12.5

ND

0.1

0.1 rat was sacrificed and the small intestine divided into the 3 segments described above which were then extracted with ice-cold $\mathrm{pH} 7.0$ Tris buffer. The extracts were centrifuged and supernatants assayed for radioactivity and chromatographed on the Mono- $Q$ column.

\section{Intestinal $\mathrm{Ca}$ absorption}

Female rats of the Fischer 344 strain were obtained from IFFA-CREDO (Les Oncins, France) at 15 wk of age. Intestinal $\mathrm{Ca}$ absorption from diets consumed during a single night was measured during wk 28 and 56 of age. For the first study examining the effect of casein phosphopeptides, the rats were fed a pelleted diet containing $0.53 \% \mathrm{Ca}$ as $\mathrm{CaCO}_{3}, 0.35 \% \mathrm{P}, 5 \%$ corn oil and $11.2 \%$ whey protein for 3 wk preceding the experiment. For the second study examining the influence of different levels of dietary casein, the rats were fed a pelleted diet containing $0.2 \%$ $\mathrm{Ca}$ as $\mathrm{CaCO}_{3}, 0.5 \% \mathrm{P}, 7 \%$ corn oil and $18 \%$ casein for 3 wk preceding the test. In both studies, the diets contained $15 \%$ sucrose, $3 \%$ cellulose, the AIN-76A concentrations of DLmethionine $(0.2 \%)$, choline bitartrate $(0.3 \%)$, vitamins and minerals (except $\mathrm{Ca}$ and $\mathrm{P}$ ), with corn starch as the major carbohydrate source.

Fractional $\mathrm{Ca}$ absorption was determined from the decrease in the ratio of ${ }^{47} \mathrm{Ca}$ to ${ }^{47} \mathrm{Sc}$ in feces relative to diet using the method of McCredie et al (1984) modified to permit inclusion of ${ }^{47} \mathrm{Ca}$ in the diet rather than giving the isotope by stomach gavage. The gamma-emitting ${ }^{47} \mathrm{Ca}\left(t_{1 / 2}\right.$ $=4.53 \mathrm{~d}$; energies of 490,810 and $1290 \mathrm{keV}$ ) decays to the gamma-emitting ${ }^{47} \mathrm{Sc}\left(t_{1 / 2}=3.43\right.$ $\mathrm{d}$; energy of $160 \mathrm{keV}$ ). Both isotopes were counted simultaneously by discrimination of their gamma energies. Since ${ }^{47} \mathrm{Sc}$ is not absorbed by the intestine, it serves as a nonabsorbable marker and thus only representative samples of both diet and feces need to be counted.

The test diets were identical to the adaptation diets except for the specific changes described in the legends to figures 3 and 4 and the addition of the radioactive tracers and food coloring. ${ }^{47} \mathrm{Ca}(50 \mu \mathrm{Ci})$ and ${ }^{47} \mathrm{Sc}(\approx 30 \mu \mathrm{Ci})$ were added to a powdered diet containing $0.01 \% \mathrm{Sc}$ as $\mathrm{ScCl}_{3}$ (a carrier for the ${ }^{47} \mathrm{Sc}$ ) and the food dye Fast Green FCF $(0.03 \%)$. The dye permitted easy identification of the radioactive feces. The diets were thoroughly mixed using a kit-chen-type blender and water was added to produce a thick paste that could be formed into pellets by hand. The formation of these pellets was facilitated by using cornstarch as the major carbohydrate source.

On the day of each experiment, the adaptation diet was removed during the morning and replaced with the radiolabeled diet in the evening just prior to darkness. The radiolabeled diet was removed the following morning and replaced with the normal diet. An advantage of this assay is that the rats consume the tests diets under normal feeding conditions. Feces were collected during the following $4 \mathrm{~d}$ with care taken to count only the green-colored radioac- 
tive feces. Throughout the experiment the rats remained in their individual plastic cages with wood chips as bedding material. Demineralized water was provided during the experiment.

A Packard Auto-Gamma counter was employed with the pre-set window for ${ }^{57} \mathrm{Co} / 75 \mathrm{Se}$ used to detect ${ }^{47} \mathrm{Sc}$ and an energy range of 360 to $1560 \mathrm{keV}$ for ${ }^{47} \mathrm{Ca}$. Diet and fecal samples were counted in plastic tubes $(11 \mathrm{~mm}$ internal diameter and $75 \mathrm{~mm}$ height) with care taken to fill each tube to a height of $56 \mathrm{~mm}$ in order to maintain counting efficiencies constant. The sample depth control was set to $2.5 \mathrm{~cm}$. Appropriate corrections were made for the $21 \%$ spillover of ${ }^{47} \mathrm{Ca}$ counts into the ${ }^{47} \mathrm{Sc}$ channel. From the ratios of ${ }^{47} \mathrm{Ca} /{ }^{47} \mathrm{Sc}$ in diets and feces, fractional $\mathrm{Ca}$ absorption was calculated as described by McCredie et al (1984).

\section{RESULTS}

\section{In vitro and in vivo stabilities of casein phosphopeptides}

During in vitro incubation of the casein phosphopeptides with extracts from rat ileum, there was a progressive rise in inorganic $P$ which reached a level of $\approx 50 \%$ of the total initial organic $P$ content of the peptides after $3 \mathrm{~h}$ (fig 1). Chromatographic analysis showed the cumulated decrease

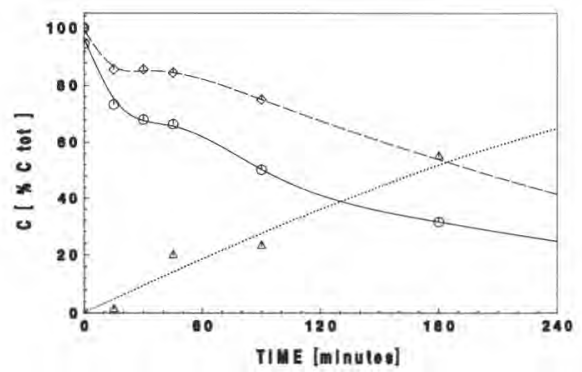

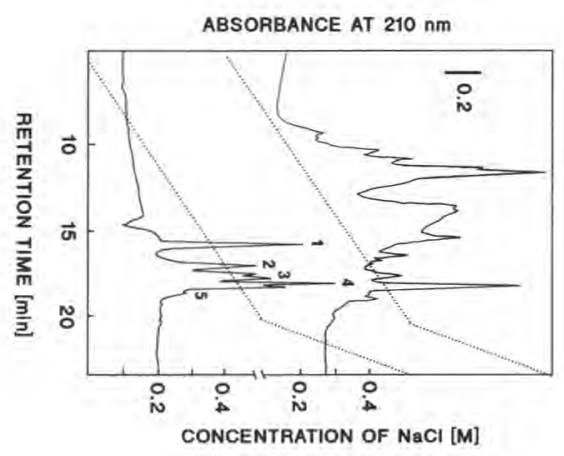

Fig 2. In vivo stability of casein phosphopeptides. FPLC profiles of the phosphopeptide preparation given to the rats (lower profile) and the ileal extract $1 \mathrm{~h}$ after stomach gavage (upper profile). The phosphopeptides are identified as follows : $\beta$-cas [33-48]; $\alpha s_{1}$-cas [43-58]; $\beta$-cas [1-28]; $\alpha s_{1}$-cas [59-79] and $\beta$-cas [1-25]; and $\alpha s_{2}$-cas $[46-70]$ for peaks 1 through 5 , respectively.

Stabilité in vitro des phosphopeptides de caséine. Le chromatogramme (FPLC) du bas représente la fraction de phosphopeptides administrée aux rats et le profil du haut représente l'extrait de l'iléum $1 \mathrm{~h}$ après gavage. Les peptides suivants ont été identifiés : 1) $\beta$-cas [3348]; 2) $\alpha s_{1}$-cas [43-58]; 3) $\beta$-cas [1-28]; 4) $\alpha s_{1-}$ cas [59-79] et $\beta$-cas [1-25]; 5) $\alpha s_{2}$-cas [46-70].

Fig 1. In vitro dephosphorylation of casein phosphopeptides by rat ileal extracts. Samples were analyzed by FPLC chromatography using a Mono-Q resin as described by Juillerat et al (1989). All data are presented as percentages of initial concentrations. The solid line represents the total of all phosphopeptide peaks, the dashed line the $\alpha_{s 1}$ [59-79] fragment, and the dotted line the release of inorganic $P$.

Déphosphorylation in vitro de phosphopeptides de caséine par des extraits d'iléum de rat. Les échantillons ont été analysés par FPLC selon Juillerat et al (1989). L'ordonnée représente le pourcentage de la concentration initiale. Les phosphopeptides totaux sont représentés par un trait plein, le fragment $\alpha_{s 1}$ [59-79] par une ligne fragmentée et le $P$ inorganique par un trait pointillé. 


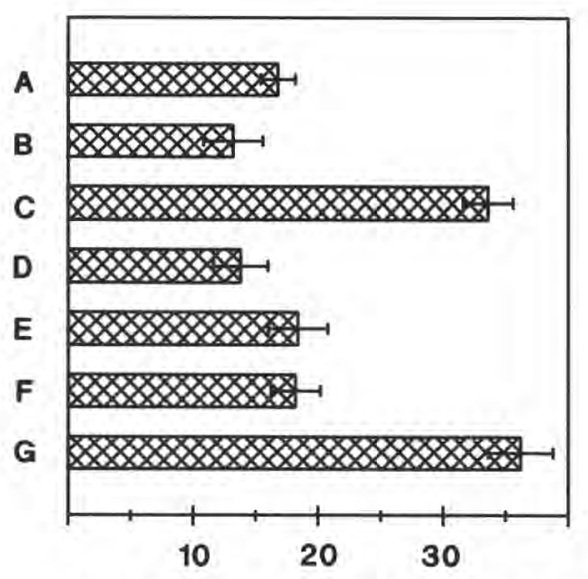

FRACTIONAL Ca ABSORPTION [ \% ] in the peak areas corresponding to all phosphopeptides. The highest rate of dephosphorylation was observed during the first $15 \mathrm{~min}$ of incubation. One of the casein fragments, $\alpha s_{1}$ [59-79], was more slowly dephosphorylated than the other fragments.

One $h$ after administration of the peptide-polyethyleneglycol mixture by stomach gavage, the main fraction of radioactivity was recovered in the ileum. Extracts of all 3 segments of the small intestine showed the duodenal and jejunal segments to be essentially devoid of phosphopeptides, while phosphopeptides were found in the ileum. Chromatographic analysis (fig 2) showed that the fragment $\alpha s_{1}$ [59-79] was the most abundant phosphopeptide present. This observation is interesting in view of the presence of a similar fragment, $\alpha s_{1}$ [66-74], found by Meisel and Frister (1988) in minipigs fed a casein meal.
Fig 3. Intestinal $\mathrm{Ca}$ absorption in rats fed diets containing $0.53 \% \mathrm{Ca}$ and $0.35 \% \mathrm{P}$. There were 8 rats in each group and data are presented as means \pm SEM. The groups were (A) $11.2 \%$ whey protein; (B) $11.2 \%$ casein; (C) $11.2 \%$ whey protein and $4 \%$ lactulose; (D) $10.3 \%$ whey protein and $1.8 \%$ phosphoserine; (E) $7.4 \%$ whey protein and $3.8 \%$ phosphopeptides; (F) $3.6 \%$ whey protein and $7.6 \%$ phosphopeptides; and (G) $3.6 \%$ whey protein, $7.6 \%$ phosphopeptides and $4 \%$ lactulose. Each diet contained $11.2 \%$ total protein. $\mathrm{CaCl}_{2}$ was used to correct for the small differences in endogenous $\mathrm{Ca}$ contents of each diet. Dietary $\mathrm{P}$ was provided by the endogenous $\mathrm{P}$ of the protein sources and $\mathrm{KH}_{2} \mathrm{PO}_{4}$. Phosphoserine was added to provide an equivalent quantity of organic $P$ as the $7.6 \%$ phosphoeptide group and lactulose replaced an equivalent quantity of cornstarch. An analysis of variance $(F$ value $=0.21 ; P>0.2)$ demonstrated that there were no significant differences in $\mathrm{Ca}$ absorption among groups A, B, D, E and F. Ca absorption was elevated in both groups receiving lactulose at $P<0.01$ as these values are outside the $99 \%$ confidence limits of the other 5 groups.

Absorption du Ca chez le rat soumis à des diètes contenant $0,53 \%$ Ca et $0,35 \% P$. Chaque groupe est composé de 8 rats et les valeurs moyennes \pm SEM sont représentées dans la figure. Les diètes sont composées de : (A) $11,2 \%$ de protéines de sérum laitier; (B) $11,2 \%$ de caséine; (C) $11,2 \%$ de protéines sériques et $4 \%$ de lactulose; (D) 10,3\% de protéines sériques et $1,8 \%$ de phosphosérine; (E) $7,4 \%$ de protéines sériques et $3,8 \%$ de phosphopeptides; (F) $3,6 \%$ de protéines sériques et $7,6 \%$ de phosphopeptides; (G) $3,6 \%$ de protéines sériques et $4 \%$ de lactulose. Le taux de protéine totale a été maintenu à 11,2\%. La concentration des diètes en $\mathrm{Ca}$ et en $\mathrm{P}$ a été maintenue à niveau constant par l'adjonction de $\mathrm{CaCl}_{2}$ et $\mathrm{KH}_{2} \mathrm{PO}_{4}$. La phosphosérine a été ajoutée en quantité correspondante à la quantité de phosphore présent dans $7,6 \%$ de phosphopeptides. Dans les diètes contenant du lactulose, ce dernier remplace en quantité équivalente l'amidon de maïs. Aucune différence significative n'a pu être mise en évidence entre les groupes $A, B, D$, E et $F$ en utilisant une analyse de variance $(F=0,21 ; P$ > 0,2 ). Seules les diètes contenant du lactulose ont provoqué une augmentation significative de l'absorption de $\mathrm{Ca}$. 


\section{Intestinal Ca absorption}

$\mathrm{Ca}$ absorption from a $0.5 \% \mathrm{Ca}$ diet as influenced by different proteins and lactulose is showed in figure 3. Ca absorption from a whey protein-based diet was not significantly different from that of a caseinbased diet nor from diets in which part of the whey protein had been replaced by casein, casein phosphopeptides or phosphoserine, while keeping the total protein

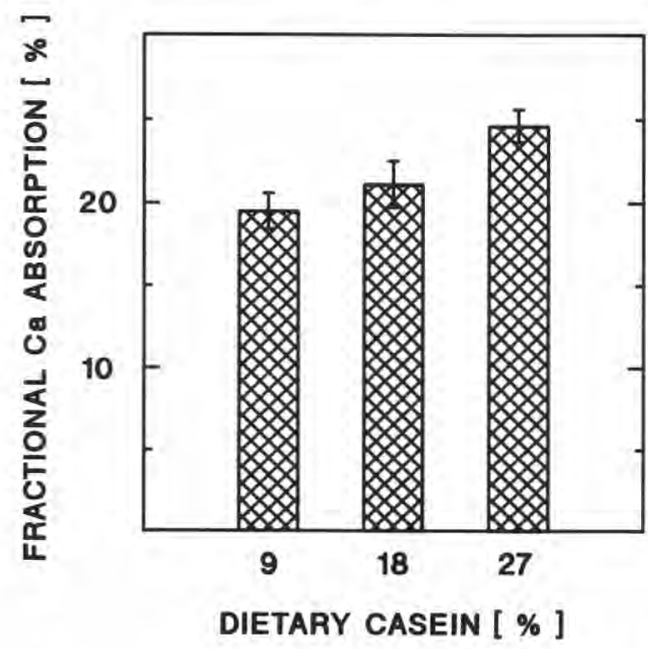

Fig 4. Fractional intestinal $\mathrm{Ca}$ absorption in rats fed diets containing different levels of casein. There were 13 rats in each group and data are presented as means \pm SEM. Due to the endogenous $\mathrm{Ca}$ and $\mathrm{P}$ contents of the casein, dietary $\mathrm{Ca}$ and $\mathrm{P}$ levels varied from 0.20 to $0.21 \%$ and 0.42 to $0.57 \%$, respectively. An analysis of variance gave a $F$ value of 4.88 indicating a significant difference among the 3 groups at $P<0.01$. Fraction du $\mathrm{Ca}$ absorbé chez le rat à partir d'un régime alimentaire contenant des quantités croissantes de caséines. Chaque groupe est composé de 13 rats. Les valeurs moyennes \pm SEM pour chaque groupe sont représentées cidessus. La concentration du $\mathrm{Ca}$ et $P$ fluctuent respectivement entre $0,20-0,21 \%$ et 0,42 $0,57 \%$. Ces variations sont dues au Ca et $P$ endogène de la préparation de caséine utilisée. Une analyse de la variance $(F=4,88)$ montre une différence significative entre ces 3 groupes $(P<0,01)$. level of the diets constant at $11.2 \%$. In contrast, addition of $4 \%$ lactulose doubled $\mathrm{Ca}$ absorption. This strong enhancement of $\mathrm{Ca}$ absorption by lactulose was not affected by the presence of the casein phosphopeptides. $\mathrm{Ca}$ absorption from a $0.2 \% \mathrm{Ca}$ diet was slightly enhanced by increasing the casein content of the diet from 9 to $27 \%$ (fig 4 ).

\section{DISCUSSION}

Several authors have suggested that casein phosphopeptides enhance intestinal $\mathrm{Ca}$ absorption. However, Pointillart and Guégen (1989) found no evidence for such an enhancement in young pigs fed chymotryptic casein phosphopeptides for 52 days. In addition, Li et al (1989) could find no evidence for a direct stimulatory effect of casein phosphopeptides on intestinal $\mathrm{Ca}$ transport in the rat ileum as these peptides inhibited the mucosal to serosal transfer of $\mathrm{Ca}$ in direct relationship to the reduction in mucosal ionized $\mathrm{Ca}$ concentrations.

In the present study, intestinal $\mathrm{Ca}$ absorption in adult female rats was measured over a period of one night while the rats maintained their normal eating patterns. Our assay readily detected the stimulatory effect of lactulose, and in other experiments (data not shown), the inhibiting effects of phytate and oxalate. Our failure to find any significant stimulation of $\mathrm{Ca}$ absorption indicates that phosphopeptides do not play a decisive role in the absorption process. This lack of stimulatory activity cannot be explained by an excessively rapid dephosphorylation or hydrolysis in the intestine as we have provided chromatographic evidence for the presence of at least part of the phosphorylated species in the ileum $1 \mathrm{~h}$ after stomach gavage.

The mechanism by which increasing levels of dietary casein enhance $\mathrm{Ca}$ ab- 
sorption is unclear but unlikely to be related to the formation of phosphopeptides since tripling the dietary casein level resulted in only a minor elevation of Ca absorption. This modest enhancement of $\mathrm{Ca}$ absorption $(26 \%)$ is not specific for casein as it is also observed with soy protein ( $R$ Brommage, unpublished results).

In light of these recent studies, a role for casein phosphopeptides in intestinal $\mathrm{Ca}$ absorption appears to be questionable.

The mechanism by which lactulose stimulates intestinal $\mathrm{Ca}$ absorption is unclear but this analogue of lactose may act in a similar manner to lactose. However, in contrast to lactose, lactulose is not metabolized in the small intestine and thus may be effective at lower dietary levels than lactose. Further experiments are underway to understand the mechanism of the stimulation of intestinal $\mathrm{Ca}$ absorption by lactulose.

\section{ACKNOWLEDGMENTS}

S Antille, F Getaz and AM Robadey provided expert technical assistance and JM Aeschlimann gave advice for the statistical analyses.

\section{REFERENCES}

Berrocal R, Chanton S, Juillerat MA, Pavillard B, Scherz JC, Jost R (1989) Tryptic phosphopeptides from whole casein. II. Physicochemical properties related to be solubilization of calcium. J Dairy Res 56, 335-341

Gerber HW, Jost R (1986) Casein phosphopeptides: Their effect on calcification of in vitro cultured embryonic rat bone. Calcif Tissue Int $38,350-357$

Holt C, Sawyer L (1988) Primary and predicted secondary structures of the caseins in relation to their biological function. Protein Eng 2, 251-259

Juillerat MA, Baechler R, Berrocal R, Chanton S, Scherz JC, Jost R (1989) Tryptic phospho- peptides from whole casein. I. Preparation and analysis by fast protein liquid chromatography. J Dairy Res 56, 603-611

Lee YS, Noruchi T, Naito H (1980) Phosphopeptides and soluble calcium in the small intestine of rats given a casein diet. Br J Nutr 43, 457-467

Li Y, Tomé D, Desjeux JF (1989) Indirect effect of casein phosphopeptides on calcium absorption in rat ileum in vitro. Reprod Nutr Dev 29, 227-233

McCredie DA, Troehler U, Bonjour JP (1984) In vivo determination of intestinal calcium absorption, with scandium 47 used as marker. $J$ Lab Clin Med 103, 354-362

Meisel H, Frister H (1988) Chemical characterization of a caseino-phosphopeptide isolated from in vivo digests of a casein diet. Biol Chem Hoppe-Seyler 369, 1275-1279

Miller DD (1989) Calcium in the diet: food sources, recommended intakes, and nutritional bioavailability. Adv Food Nutr Res 33, 103154

Naito H, Kawami A, Imamuira T (1972) In vivo formation of phosphopeptide with calciumbinding property in the small intestinal tract of the rat fed on casein. Agric Biol Chem 36, 409-415

Oesterberg R (1966) Phosphorylated peptides, study of their primary structure and metal complexity. Ph D Thesis, Uppsala, Sweden

Pointillart A, Guégen L (1989) Absence d'effet de l'incorporation d'un phosphopeptide du lait sur l'utilisation du calcium et du phosphore chez le jeune porc. Reprod Nutr Dev 29, 477 486

Reeves RE, Latour NG (1958) Calcium sequestering phosphopeptide from casein. Science 128,472

Steichen J, Tsang RC (1987) Bone mineralization and growth in term infants fed soy-based or cow milk-based formula. J Pediatr 110 , 687-692

Van Veldhoven PP, Mannaerts GP (1987) Inorganic and organic phosphate measurements in the nanomolar range. Anal Biochem 161, 45-48

Ziegler EE, Fomon SJ (1983) Lactose enhances mineral absorption in infancy. J Pediatr Gastroenterol Nutr 2, 288-294 